\title{
ARTIGOS
}

\section{Cotton resistance to ramulose and variability of Colletotrichum gossypii f. sp. cephalosporioides}

\author{
Jefferson Fernandes do Nascimento ${ }^{1}$, Laércio Zambolim², Francisco Xavier Ribeiro do Vale ${ }^{2}$, Paulo Geraldo Berger ${ }^{3}$, \\ Paulo Roberto Cecon ${ }^{4}$
}

\begin{abstract}
${ }^{1}$ Departamento de Fitotecnia, Universidade Federal de Roraima, Boa Vista, RR, ${ }^{2}$ Departamento de Fitopatologia, Universidade Federal de Viçosa, 36.570.000, Viçosa, Minas Gerais, E-mail: Zambolim@ufv.br, ${ }^{3}$ Departamento de Fitotecnia, Universidade Federal de Viçosa, 36.570.000, Viçosa, Minas Gerais, ${ }^{4}$ Departamento de Informática, Universidade Federal de Viçosa, 36.570.000, Viçosa, Minas Gerais. Autor para correspondência: Laércio Zambolim <zambolim@ufv.br> Data de chegada: 26/09/03. Aceito para publicação em: 28/06/04.
\end{abstract}

\begin{abstract}
Nascimento, J. F.; Zambolim, L.; Vale, F. X. R.; Berger, P. G.; Cecon, P. R. Cotton resistance to ramulose and variability of Colletotrichum gossypii f. sp. cephalosporioides. Summa Phytopathologica, v.32, p. 9-15, 2006.

Four cultivars and 21 lines of cotton were evaluated for resistance to ramulose (Colletotrichum gossypii f. sp. cephalosporioides) in a field where the disease is endemic. The seeds of each genotype were planted in 5 x 5 m plots with three replications. The lines CNPA 94101 and 'CNPA Precoce 2'were used as standard susceptible and resistant references, respectively. The disease incidence (DI) was calculated from the proportion of diseased plants in the plot. The disease index (DIn) was calculated from the disease severity using a 1 to 9 scale, and was evaluated at weekly intervals starting 107 days after emergence. The data collected was used to calculate the area under disease progress curve (AUDPC). In general, the DIn increased linearly with time and varied from 20.0 to 57.1 and AUDPC from 567 to 1627 among the genotypes which could be clustered in to two distinct groups. The susceptible group contained two cultivars and nine lines and the resistant group contained one cultivar and 12 lines. The relationship between disease index and evaluation times was linear for the 25 genotypes

most susceptible with an average DI $=83.4$, DIn $=57.1$ and AUDPC $=1627.7$. The line CNPA 96-08 with DI $=37.8$, DIn $=20.0$ and AUDPC $=567.7$ was the most resistant one. Among the commercial cultivars 'IAC 22' was the most susceptible and 'CNPA Precoce 2', used as resistant standard was the most resistant.

The variability in virulence of the pathogen was studied by spray inoculating nine genotypes with conidial suspensions $\left(10^{5} / \mathrm{mL}\right)$ of either of the 10 isolates. The disease severity was evaluated 30 days later using a scale of 1 to 5 . The virulence of the isolate was expressed by DIn. All the isolates were highly virulent but their virulence avaried for several genotypes and could be clustered in two distinct groups of less and more virulent isolates. The isolate MTRM 14 from Mato Grosso was the least virulent while Minas Gerais was the most virulent, with DIn of 6.36 and 46.47, respectively. In this experiment the line HR 102 and the cultivar 'Antares' were the most resistant ones with DIns of 18.32 and 19.14, respectively.
\end{abstract} tested. The line CNPA 94-101, used as susceptible standard, was the

Additional key words: Gossypium sp., virulence.

\section{RESUMO}

Nascimento, J. F.; Zambolim, L.; Vale, F. X. R.; Berger, P. G. \& Cecon, P. R. Resistência do algodoeiro a ramulose e variabilidade de Colletotrichum gossypii f. sp. cephalosporioides. Summa Phytopathologica, v.32, p. 9-15, 2006.

A resistência de quatro cultivares e 21 linhagens de algodão a ramulose (Colletotrichum gossypii f. sp. cephalosporioides ) foi avaliada em condições de campo, sob infecção natural, em látice quadrado de 5 x 5 com três repetições, em área onde a doença ocorre endemicamente. As linhagens CNPA 94-101 e CNPA precoce 2 foram empregadas como padrão de suscetibilidade e resistência, respectivamente. Na avaliação empregou-se a incidência (Inc.) e a severidade (notas de um a nove) a qual serviu de base para o cálculo do índice de doença (ID) e a área abaixo da curva do progresso da ramulose (AACPD). O índice de doença variou de 20,0 a 57,1 e a AACPD de 567 a 1627 . Os resultados 
permitiram separar os genótipos em dois grupos dintintos: um formado por duas cultivares e nove linhagens suscetíveis e o outro formado por uma cultivar e doze linhagens resistentes. $O$ índice de doença mostrou crescimento linear em função do tempo para os 25 genótipos estudados. A linhagem (CNPA 94-01-padrão de suscetibilidade) apresentou Inc-83,4, ID-57,1 e AACPD-1627,7; a linhagem CNPA 96-08 apresentou Inc-37,8, ID-20,0 e AACPD-567,7 a mais resistente. Dentre as cultivares comerciais a IAC 22 foi a mais suscetível, com Inc-69,3, ID47,3 e AACPD-1322,7. A cultivar resistente padrão apresentou: Inc45,1, ID-28,9 e AACPD-824,1. Para o estudo da variabilidade de $C$. gossypii f. sp. cephalosporioides empregou-se dez isolados do patóge-

Palavras-chave adicionais: Gossypium spp., virulência. no na concentração de $10^{5}$ conídios/mL e nove genótipos de algodoeiro. Adotou-se delineamento em blocos ao acaso com três repetições em esquema fatorial de $9 \times 10$. A avaliação foi feita trinta dias após a inoculação das plantas, empregando-se uma escala de notas de um a cinco.

Calculou-se o ID para se expressar a virulência dos isolados. O isolado MTRM 14 de Mato Grosso teve baixa virulência e o isolado RAV 20 de Minas Gerais foi o mais virulento, com ID 6,3 e 46,7, respectivamente. A linhagem $\mathrm{HR}$ e a cultivar Antares foram as mais resistentes com ID 18,3 e 19,1, respectivamente. Mediante análise de agrupamento foi possível separar os isolados em dois grupos: virulentos e de baixa virulência.
Colletotrichum gossypii (anamorph Glomerella gossypii), normally causes anthracnose in cotton, but a virulent form, $C$. gossypii f. sp. cephalosporioides, prevalent in Latin America causes ramulose (4). The symptoms are similar that of anthracnose, but only $C$. gossypii f. sp. cephalosporioides produces ramulose syndrome characterized by apical meristem mortality resulting in excessive lateral bud sprouting giving the plants a ramulated appearance. The diseased plants are stunted with short inter-nodes with dry and coarse areas. Pre-bloom infection can lead to flower abortion and in extreme cases plants become totally unproductive (17). The pathogen is transmitted by the seeds $(23 ; 24)$. Presently it is the most important cotton disease in the Brazilian savanna, favored by high rainfall and warm temperatures $\left(25\right.$ to $\left.30{ }^{\circ} \mathrm{C}\right)$. The disease severity is high if infection occurs in less than 60-day old plants, because the new branches emitted after the apical meristem death also become diseased ( 8 , $17,18)$. Depending upon the climatic conditions and cultivar susceptibility yield losses can reach more than $85 \%(6,8,18)$.

Several cultivars and lines have been reported to be resistant to ramulose in the field and in the greenhouse tests. Carvalho et al. (6) selected field resistant genotype 'La 17801', HR 100, HR101, and HR 102. In the later study Carvalho et al. (7) considered HR 102, from USA, as a good source of resistance and a good option for breeding program based on selection of segregating generations from hybridization. Its improved populations $\left(\mathrm{C}^{2}\right.$ and $\mathrm{C}^{3}$ ) were found to be an excellent source of resistance to be incorporated in breeding program (25). In greenhouse evaluations of 35 cotton genotypes of Brazilian and American origin, American cultivars 'Acala 3080', 'Coker 310', 'Stoneville 731N' and 'Coker 4360' were found to be resistant, but in field evaluation 'Des 56', 'Coker 220', Hy Bee 200A' and 'Locket 77' were more resistant, which suggested that greenhouse tests could be used in the initial evaluation, while field tests would be necessary for advanced selection (31). In a field evaluation of five genotypes and 20 F-1 hybrids 'CNPA 'precoce 1' was found to be most resistant, and the lines with okra type leaves, and 'CNPA $7 \mathrm{H}$ ' as the most susceptible. The 'Embrapa 114' and 'CNPAITA 96' obtained cotton breeding program of Mato Grosso savanna, showed good resistance to ramulose and tolerance to fusariumnematode complex (1), but were susceptible to Stemphylium, Alternaria and Bacterial leaf spots (14). The 'ITA 92-63', 'ITA 91-18', 'Sicala 34' and 'CS 189' are reported to be more tolerant to ramulose and more productive than 'IAC 20', presently recommended and most cultivated in the Rondonia state (16). In Uberaba, Minas Gerais, among the 24 genotypes evaluated, 'HD24',
'HD20' and 'OSF' were the most resistant.

The pathogenic variability of Colletotrichum is well documented $(4,29)$, and most of the work has been done by evaluating only the disease severity on artificially inoculated plants $(5,22$, 31 ). The knowledge of physiological variation of C. gossypii $\mathrm{f}$. sp. cephalosporioides is essential for a meaningful cotton breeding program. Recently Bailey et al. (4) studied the taxonomic position of Colletotrichum, including C. gossypii and C. gossypii f. sp. cephalosporioides, $C$. gloesporioides f. sp. malvae and $C$. malvarum and found that the isolates from cotton differed from those of other malvaceae. The rDNA sequence comparison showed C. gossypii and C. gossypii f. sp. cephalosporioides being identical with $99.5 \%$ homology therefore did not justify a distinct species. A high homology of $97 \%$ was also found among different species of Colletotrichum, including some isolates of $C$. gloeosporioides, which lead the authors to suggest that the cotton isolates should be considered as forma speciales of $C$. gloeosporioides. Since the work of Bailey et al. (4) has not been confirmed by other studies, in the following work the original nomenclature of Costa \& Fraga Junior (9) was maintained.

Lima \& Chaves (24) while studying the variability of monoconidial isolates of $C$. gossypii f. sp. cephalosporioides, showed variation in virulence on different genotypes including different reactions to different isolates. Similar results were found by Tanaka $\&$ Menten (29) where five of the six isolates differed significantly in their pathogenicity on six cotton genotypes. Such finding indicate existence of races of $C$. gossypii f. sp. cephalosporioides and incomplete vertical resistance.

Use of resistant and productive cultivars is the most economical and desirable control measure for cotton ramulose. Great efforts have being done during the years, in Brazil, to identify cotton sources of resistance to the disease $(5,19,22,31)$. But there are several reports of cultivar resistant in one region becoming susceptible in another, which compels continued evaluation of genotypes and at the same time little is known about the variability of the pathogen. The following study was done to evaluate cotton cultivars and lines for field resistance to $C$. gossypii f. sp. cephalosporioides and study the physiological variability of the pathogen.

\section{MATERIAL AND METHODS}

Resistance of cotton genotypes to ramulose: The experiment was done in the experimental field area of the Federal University of Viçosa situated at altitude of $689 \mathrm{~m}$, latitude $20^{\circ} 45^{\prime} \mathrm{S}$ 
and longitude $42^{\circ} 51 \mathrm{~W}$. The planting was done on November 14 , 1997, seedling emergence occurred in 7 days and 25 days after emergence (DAE) the stand was thinned to five plants/ meter. The disease is endemic in the area $(1,27)$. The line CNPA-94101 and the cultivars 'CNPA- Precoce 2' were included in the study as susceptible and resistant standards, respectively. The daily climatic data regarding maximum and minimum temperatures, relative humidity and rainfall were collected from the meteorological station situated in the experimental area.

The cotton cultivars and lines were supplied by the National Research Center of Cotton (CNPA-EMBRAPA), Campina Grande, Paraíba, Brazil (Table-2). The experiment was laid in the randomized complete block design with three replication of $5 \mathrm{~m}$ square plots with four planting rows $1 \mathrm{~m}$ apart but, the common lateral border lines were planted to CNPA $7 \mathrm{H}$. The usable plot area was represented by the middle two rows, giving the plot area of $10 \mathrm{~m}^{2}$. For statistical analysis, split-plot scheme was used, having the genotypes as the main plot and days after emergence DAE as subplots.

The disease severity was evaluated at weekly interval starting 107 DAE till 135 DAE, using the modified note-scale of Costa (10): 1-no symptoms; 2- few necrotic lesions on leaves; 3- many necrotic lesions on leaves; 4-short upper inter-nodes; 5- short inter-nodes together with excessive lateral bud sprouting; 6 - short inter-nodes with excessive lateral bud sprouting and possibility of producing more than three fruits/plant; 7 - short inter-node with excessive lateral bud sprouting and impossibility of producing none or less than three fruits/plants; 8 - very high lateral bud proliferation and plant stunting; 9 - as in 8 with no fruits. The disease index (DIn) was calculated according to McKinney (26):

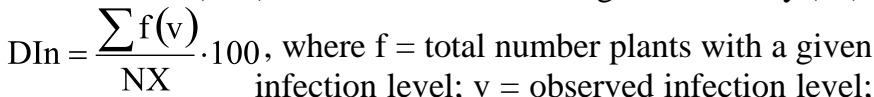
$\mathrm{N}=$ total number of plants evaluated; $\mathrm{X}=$ maximum infection level. The disease incidence (DI) is the proportion of diseased plants in a plot. The area under the disease progress curve (AUDPC) was calculated from the temporal DIn using the software AVACPD (30). The statistical analyses were done using the software S. A. E. G. (11). The evaluated characteristics were analyzed to individual variance. The criteria for selecting the regressing models were based on high determination coefficient $\left(\mathrm{r}^{2}\right)$; coeffi- cient significance up to $5 \%$ probability by F-test and biological significance of the model.

Variability in virulence of Colletotrichum gossypii f. sp. cephalosporioides

The variability in the virulence of 10 isolates (Table 1) was evaluated on four commercial cultivars and five lines of Gossypium hirsutum L. var. latifolium in a greenhouse. Five isolates were obtained from leaves and branches of affected cotton growing in Viçosa, Minas Gerais and the remaning five isolates were received from other cotton producing areas of the country.

The pathogenicity of all the isolates was priorly tested on CNPA 7H. All The genotypes used in this study were supplied by CNPA-EMBRAPA, of which CNPA 96-08, CNPA 96-09, HR 102, CNPA 96-40, 'ITA 96' and 'Antares' were considered as resistant standards, and 'CNPA 7H' and CNPA 94-101 as susceptible standard. Thirty fungicide treated seeds $(0.4 \%)$ were sown in wooden trays $(45 \times 45 \times 14 \mathrm{~cm})$ filled with $20 \mathrm{~kg}$ of soil: manure (4:1) mix and two weeks after emergence the stand was reduced to 15 seedlings/ tray. The seedlings of each genotype, 30 days after emergence, were spray inoculated separately with a conidial suspension $\left(10^{5} / \mathrm{mL}\right)$ of each of the fungal isolates. The sprays were directed towards the apical meristem and new permanent leaves (6). The inoculated plants were incubated for $48 \mathrm{~h}$ in a mist chamber at $22 \pm 1{ }^{\circ} \mathrm{C}$, and then transferred to the greenhouse and irrigated daily. The disease severity was evaluated at five day interval from 15 to 30 days after inoculation using the 1 to 5 scale of Carvalho et al. (8): 1- no symptoms; 2-only necrotic lesion on leaves; 3 - short upper nodes, with or without excessive bud sprouting; 4- very excessive bud sprouting with plant stunting; 5 - as in 4 but much more severe. The virulence of the isolate was expressed by DIn, calculated from the formula mentioned and AUDPC was calculated from temporal changes in DIn. The experiment was laid in randomized complete block design with three replications. After the analysis of variance the means were compared using Tukey's test $(\mathrm{p}=0.5)$. The isolates of similar virulence were grouped by cluster analysis of AUDPC.

\section{RESULTS}

Resistance of cotton genotype to ramulose: The field incidence of ramulose was high, along with high variation in geno-

Table 1 -The isolates of Colletotrichum gossypii f. sp. cephalosporioides used in the variability studies.

\begin{tabular}{|c|c|c|c|c|}
\hline Isolate & Locality & Plant Part & Genotype & Date \\
\hline RAV 31 & Viçosa - MG & Leaf and shoot & Antares* & January 99 \\
\hline PR10938 & São João do Ivaí - PR & Leaf and shoot & IAC $20 *$ & December 93 \\
\hline MTRM 14 & Campo Verde - MT & Leaf and shoot & ITA $96^{*}$ & July 95 \\
\hline RAV 16 & Viçosa - MG & Leaf and shoot & CNPA $94-101 * *$ & March 98 \\
\hline RAV 4 & Viçosa - MG & Leaf and shoot & CNPA $7 \mathrm{H}^{*}$ & March 98 \\
\hline MGA 30 & Uberaba - MG & Shoot & ELITE* & December 97 \\
\hline RAV 30 & Viçosa - MG & Leaf and shoot & ITA $96^{*}$ & January 99 \\
\hline
\end{tabular}

*Cultivar; **Line 
type response to the disease. Although there was a significant effect of genotype and the evaluation time DAE on the disease, the interaction between the two was nonsignificant. The average DI varied from 37.8 to 83.4, DIn from 20.0 to 57.1 and AUDPC from 567.7 to 1627.6. Based on these criteria cluster analysis of Scott-Knot grouped the genotypes into two groups (Table 2). For DIn and AUDPC the susceptible group was formed by cultivars 'IAC 20' and 'IAC 22', and the lines CNPA 94-101, CNPA TB91, CNPA TB80, CNPA 96-121, CNPA 94-108, CNPA 96-16, CNPA TB 90, CNPA TB41 and CNPA TB55. The resistant group was composed of cultivars 'CNPA Precoce 2' and the lines CNPA TB85, CNPA TB15, CNPA TB87, CNPA 96-21, CNPA TB75, CNPA TB93, CNPA 94-139, CNPA 96-39, CNPA TB66, CNPA 96-09, CNPA 96-40 and CNPA 96-08.

The line CNPA 94-101 showed maximum DI, DIn, and AUDPC, therefore was considered as the most susceptible, and the lowest DI, DIn and AUDPC was found in line CNPA 96-08, classified as the most resistant. Of the commercial cultivars 'IAC 22' was the most susceptible and 'CNPA Precoce 2" was the most resistant with AUDPC of 1322.7 and 824.1, respectively.

In general the DIn increased linearly in all the genotypes as exemplified in the Figure 1 and 2. In the noncommercial, the most resistant line CNPA 96-08, the DIn of 6.9 at 107 DAE increased to 31.5 at 135 DAE, while in the most susceptible, CNPA 94-

Table 2: Mean cotton ramulose disease incidence (DI), disease index (DIn) and area under the disease progress curve (AUDPC) evaluated at $107,114,120,128$ and 135 days after emergence in field.

\begin{tabular}{llll}
\hline Cultivar/Line & DI $(\%)$ & DIn & AUDPC \\
\hline 1.CNPA 94-101 & $83.4 \mathrm{a}^{*}$ & $57.1 \mathrm{a}^{*}$ & $1627.6 \mathrm{a}^{*}$ \\
2.CNPA TB91 & $79.7 \mathrm{a}$ & $53.1 \mathrm{a}$ & $1499.9 \mathrm{a}$ \\
3.CNPA TB80 & $78.7 \mathrm{a}$ & $50.4 \mathrm{a}$ & $1453.1 \mathrm{a}$ \\
4.CNPA 96-121 & $78.6 \mathrm{a}$ & $50.2 \mathrm{a}$ & $1432.1 \mathrm{a}$ \\
5.CNPA 94-108 & $73.3 \mathrm{a}$ & $47.5 \mathrm{a}$ & $1377 . \mathrm{a}$ \\
6.CNPA 96-16 & $72.4 \mathrm{a}$ & $45.7 \mathrm{a}$ & $1322 . \mathrm{a}$ \\
7.CNPA TB90 & $71.5 \mathrm{a}$ & $46.8 \mathrm{a}$ & $1119.3 \mathrm{a}$ \\
8.IAC 22 & $69.3 \mathrm{a}$ & $47.3 \mathrm{a}$ & $1322,7 \mathrm{a}$ \\
9.CNPA TB41 & $68.0 \mathrm{a}$ & $45.8 \mathrm{a}$ & $1286.3 \mathrm{a}$ \\
10.CNPA TB55 & $67.2 \mathrm{a}$ & $42.1 \mathrm{a}$ & $1219.1 \mathrm{a}$ \\
11.IAC 20 & $66.5 \mathrm{a}$ & $41.2 \mathrm{a}$ & $1185.4 \mathrm{a}$ \\
12.CNPA TB85 & $65.8 \mathrm{a}$ & $36.8 \mathrm{~b}$ & $1061.7 \mathrm{~b}$ \\
13.CNPA TB15 & $64.3 \mathrm{a}$ & $38.4 \mathrm{~b}$ & $1114.9 \mathrm{~b}$ \\
14.CNPA 7H & $63.6 \mathrm{a}$ & $34.3 \mathrm{~b}$ & $1005.7 \mathrm{~b}$ \\
15.CNPA TB87 & $61.4 \mathrm{~b}$ & $32.8 \mathrm{~b}$ & $950.9 \mathrm{~b}$ \\
16.CNPA 96-21 & $60.8 \mathrm{~b}$ & $33.1 \mathrm{~b}$ & $965.7 \mathrm{~b}$ \\
17.CNPA TB75 & $60.1 \mathrm{~b}$ & $34.7 \mathrm{~b}$ & $1005.5 \mathrm{~b}$ \\
18.CNPA TB93 & $58.8 \mathrm{~b}$ & $33.8 \mathrm{~b}$ & $981.3 \mathrm{~b}$ \\
19.CNPA 94-139 & $58.5 \mathrm{~b}$ & $31.9 \mathrm{~b}$ & $919.1 \mathrm{~b}$ \\
20.CNPA 96-39 & $57.5 \mathrm{~b}$ & $33.9 \mathrm{~b}$ & $966.8 \mathrm{~b}$ \\
21.CNPA TB66 & $51.5 \mathrm{~b}$ & $25.6 \mathrm{~b}$ & $740.6 \mathrm{~b}$ \\
22.CNPA 96-09 & $51.4 \mathrm{~b}$ & $27.6 \mathrm{~b}$ & $803.0 \mathrm{~b}$ \\
23.CNPA 96-40 & $46.2 \mathrm{~b}$ & $26.2 \mathrm{~b}$ & $740.0 \mathrm{~b}$ \\
24.CNPA Precoce2 & $45.1 \mathrm{~b}$ & $28.9 \mathrm{~b}$ & $824.1 \mathrm{~b}$ \\
25.CNPA 96-08 & $37.8 \mathrm{~b}$ & $20.0 \mathrm{~b}$ & $567.7 \mathrm{~b}$ \\
\hline
\end{tabular}

* Means followed by the same letter in a column do not differ by ScottKnot grouping tests $(\mathrm{p}=0.5)$.
101, it was 45.0 and 69.4 on the respectively DAE (Figure 1). The most resistant commercial cultivar 'CNPA Precoce 2' had DIn of 45.9 and the most susceptible 'IAC 22' 77.8 at 135 DAE. The AUDPC for susceptible line CNPA 94-101 and the cultivar 'IAC 22 ' are shown in Figure 3B along with the climatic data (Figure 2 ), where in the former the DIn of 42.0 at 107 DAE increased to 65.0 at $135 \mathrm{DAE}$, and in 'IAC 22' it increased from 14.0 to 72.0 in the same period.

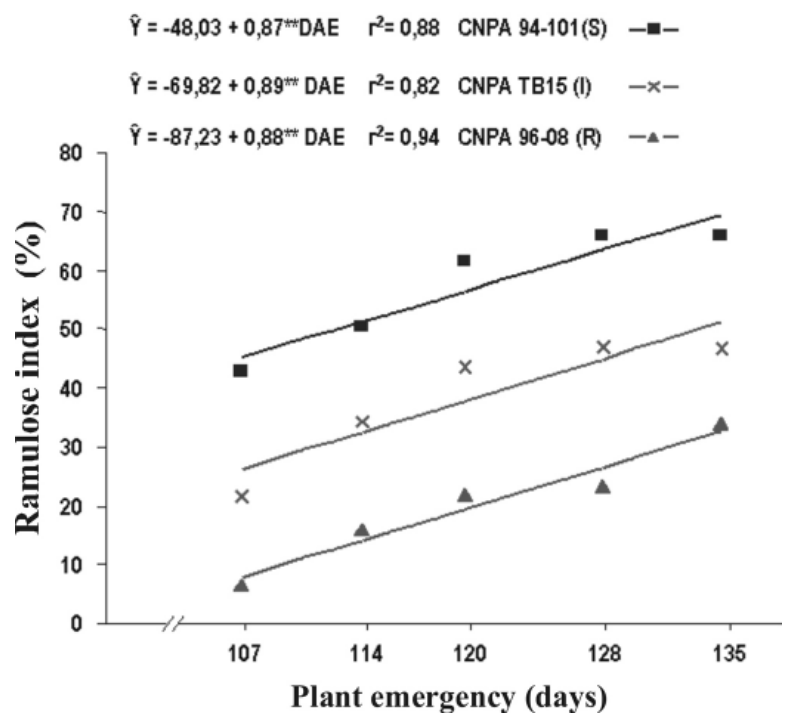

Figure 1. Estimated ramulose index (Colletotrichum gossypii f. sp. cephalosporioides) in three cotton lines (CNPA 94-101, CNPA TB 15 and CNPA 96-08) at various days after plant emergence.

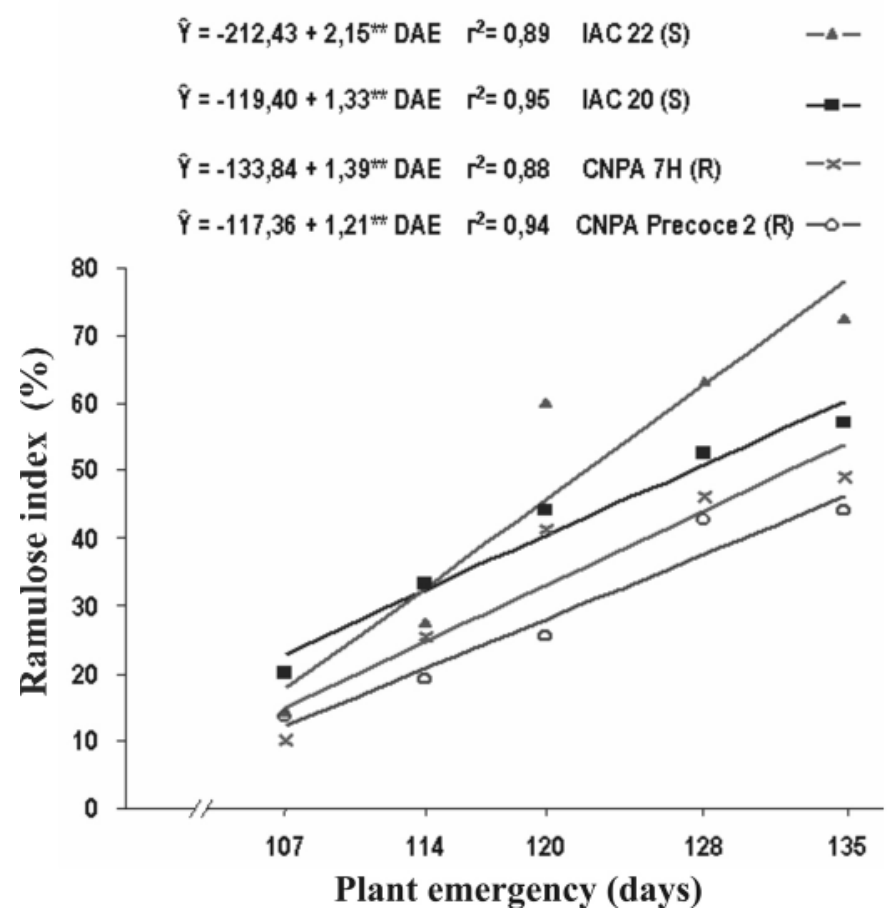

Figure 2. Estimated index of ramulose (Colletotrichum gossypii f. sp. cephalosporioides) in four commercial cotton cultivars (IAC 22, IAC 20, CNPA 7H and CNPA early 2) at various days after plant emergence. 
Physiological variability of Colletotrichum gossypii f. sp. cephalosporioides

The isolates and cultivars differed significantly as to DIn and its relation to DAE (Table 3 ). The initial symptoms began to appear three to four days after inoculation, as small necrotic spots on the leaves, veins and petioles, followed by the apical meristem necrosis, but the intensity of symptoms varied with the isolate and the genotype. The isolate MTRM 14, PB 7581 and PR 10938 were the least and similarly virulent with DIn of 6.36, 15.52 and 17.87, respectively and the isolate RAV 20 was the most virulent with DIn of 46.47. The DIn among the genotypes varied from 18.3 to 40.3 , classifying the cultivar 'Antares' and the line HR 102 as resistant, and 'CNPA 7H' and 'IAC 20' as very susceptible.

A dendrogram was constructed using AUDPC data to determine the similarity among the isolates, using cluster analysis of nearest neighbor method. Considering distance limit of 600 Euclidean, the isolates were separated into two distinct groups of less and more virulent isolates with most of the isolates being virulent (Figure 4, Table 3).

\section{DISCUSSION}

Various methods are available for evaluating disease resistance (26), but use of AUDPC is the most recommended, becau-

Table 3. Mean disease index of cultivars and lines of cotton inoculated with any of the 10 isolates of Colletotrichum gossypii f. sp. cephalosporioides.

\begin{tabular}{ll}
\hline Isolate & Disease index \\
\hline 1.RAV 20 & $46.47 \mathrm{a}$ \\
2.RAV 4 & $38.24 \mathrm{ab}$ \\
3.RAV 30 & $37.11 \mathrm{ab}$ \\
4.RAV 16 & $36.77 \mathrm{ab}$ \\
5.RAV 31 & $34.56 \mathrm{ab}$ \\
6.MGA 30 & $30.34 \mathrm{bc}$ \\
7.SP 6236 & $24.63 \mathrm{bcd}$ \\
8.PR 10938 & $17.87 \mathrm{cde}$ \\
9.PB 7581 & $15.52 \mathrm{de}$ \\
10.MTRM 14 & $6.36 \mathrm{e}$ \\
Cultivar/Line & \\
1.CNPA 7H & \\
2.IAC 22 & $40.33 \mathrm{a}$ \\
3.CNPA 94-101 & $40.32 \mathrm{a}$ \\
4.CNPA 96-40 & $33.76 \mathrm{ab}$ \\
5.ITA 96 & $32.07 \mathrm{~b}$ \\
6.CNPA 96-09² & $26.96 \mathrm{bc}$ \\
7.CNPA 96-08 & $26.16 \mathrm{bcd}$ \\
8.ANTARES & $22.03 \mathrm{cde}$ \\
9.HR 102 & $19.14 \mathrm{de}$ \\
CV $(\%)$ & $18.32 \mathrm{e}$ \\
\hline
\end{tabular}

Means followed by the same letter do not differ by Scott-Knot grouping tests $(\mathrm{p}=0.5)$

${ }^{1}$ Cultivar; ${ }^{2}$ Line. se besides using all the data of different evaluation dates, it is not affected by transformation that can influence the disease development rate $(3,20)$. In this study CNPA 94-101, used as standard susceptible showed maximum DI, DIn and AUDPC. Among the genotypes there was very high variability for resistance to ramulose. Such type of variation has been reported by many other workers $(2,6,15,22,31)$. Andrade et al. (2) observed significant differences in resistance of 18 genotypes in the field conditions of Mato Grosso do Sul and classified 'CNPA 7H' as the most susceptible with disease severity of 4.5 in 1 to 5 scale, and the 'Deltaopal' and 'Antares' as good options for that region. In the present study on the basis of DI, DIn and AUDPC the four commercial cultivars and 21 lines could be grouped only into two groups. In the resistant group the line CNPA 96-08 showed the least DI, DIn, and AUDPC (567.7) and the cultivar
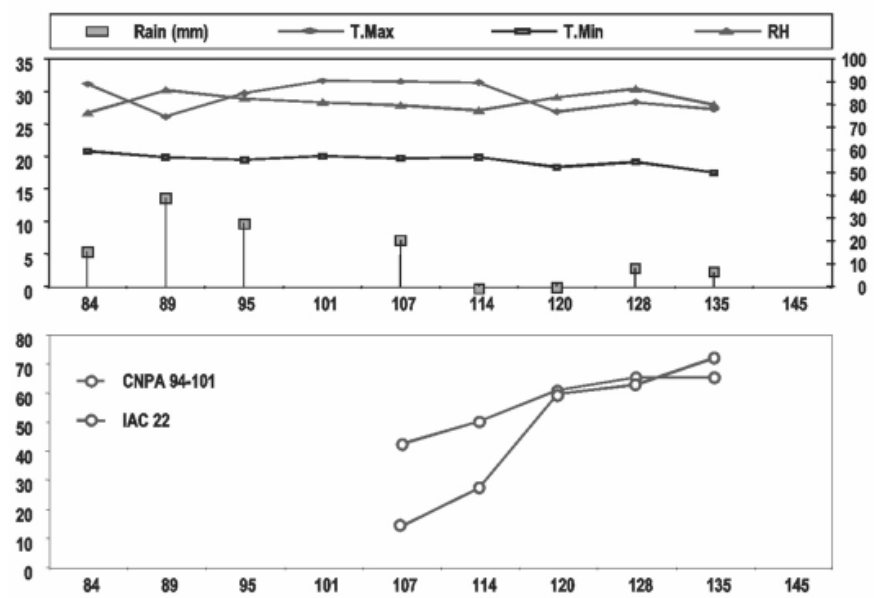

Figure 3. Rain fall, relative humidity, and maximum and minimum temperatures in the experimental field during the trial period evaluating cotton genotype reaction to ramulose (A), and mean ramulose index (\%) in cotton line 94-101 and cultivar IAC 22 (B).

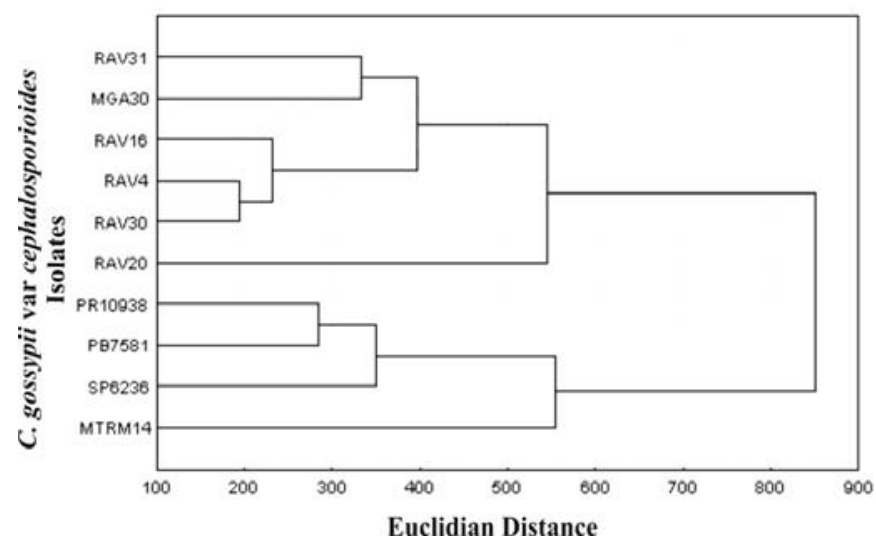

Figure 4. Grouping of 10 isolates of Colletotrichum gossypii f. sp. cephalosporioides according to area under the disease progress curve in four cultivars and five lines of cotton using the Nearest Neighbor Method. 
'CNPA Precoce 2', used as standard resistant had an AUDPC of 824.1. The lines CNPA TB66 and CNPA 96-40 also were resistant with AUDPC below 750. Among the susceptible the lines CNPA 94-101, CNPA TB 91, CNPA TB 80, and CNPA 96-121 the AUDPC varied from 1400 to 1630.

Among the 35 genotypes evaluated by Von Pinho et al. (31), 'IAC 20' (selection from IAC 17) showed an intermediate reaction in field, but in this study along with 'IAC 22' and 'CNPH 7 H'it was found to be very susceptible. These results are similar to those reported by Farias et al. (12) who reported all the three genotypes as susceptible. 'CNPH 7H' was also reported as susceptible by Andrade et al. (2) in Mato Grosso do Sul. Response of cultivar to the disease in field conditions can be affected by climatic variations (31). The influence of relative humidity and rainfall has reported by various authors. Santos et al. (27) studied the progress of ramulose in field grown cotton and found that linear tendency of the disease increase from the inoculum source till 123 DAE, coinciding with mean weekly temperature of 12.8 ${ }^{\circ} \mathrm{C}$. The disease had spread to a distance of $9 \mathrm{~m}$ from the inoculum source in just 46 DAE e. g. $1 \mathrm{~m}$ every 5 days. In this study the disease index in all the genotypes increased during the evaluation period when the relative humidity remained above $75 \%$ and maximum and minimum temperature about $30^{\circ} \mathrm{C}$ and $20^{\circ} \mathrm{C}$ respectively, suggesting that these climatic variable are important for disease severity increase in the field. Besides the temperature and relative humidity, the rainfall may have great influence on the disease development, because of mean rainfall (14 mm), 18 days prior to first evaluation.

Evaluation of cotton genotypes for resistance to $C$. gossypii f. sp. cephalosporioides are being done along the years $(2,6,12$, $22,31)$ and need to be continued in search for new sources of resistance. Since there is great variation in genotypes response to disease in different regions, there is a necessity of field tests at each locality before recommending the cultivars

The high variation among the isolates was represented by symptomatological variation on different genotypes. On an average the isolate MTRM 14 was the least and RAV 20 was the most virulent, with genotype average DIn of 6.36 and 46.47, respectively. Similar variation was reported by Lima \& Chaves (24), who studied the virulence variability of 10 monoconidial isolates of C. gossypii f. sp. cephalosporioides on 10 cotton genotypes and postulated existence of races of the pathogen. This view was supported by Tanaka \& Menten (29) who additionally suggested existence of incomplete vertical resistance in cotton sensu Parlevliet (26). In the present study, the virulence of all the isolates and reaction of each genotype to each isolate differed significantly, but the nonsignificant genotype $\mathrm{x}$ isolate interaction characte rizes existence of horizontal resistance.

Among the genotypes classified as resistant to ramulose in the present work, some had been tested earlier in field in Pernambuco state; Lima et al. (25) while developing resistant lines through recurrent selection, concluded that the improved populations of HR 102 (C-1 and C-3) were excellent source of resistance, which was confirmed in this and other studies $(6,7)$, and has lead many authors to consider this line as a good source of resistance to be used in cotton breeding. Variation in disease response to different isolates also occurred in the commercial cultivars, with 'Antares' being most resistant to all ten isolates, and a similar behavior of this cultivar was found in the central-west savanna (13), and 'ITA 96' with DIn of 26.96 was intermediately resistant, whi- ch Freire et al. (14) had classified as resistant. The high susceptibility of 'CNPA 7H' and 'IAC 22'reported from Mato Grosso do Sul (2) and savanna of Mato Grosso (12) and Minas Gerais (1) was confirmed in this work.

The resistance of a genotype results from the interaction between the pathogen and the host. The cluster analysis separated the 10 isolates into two, the virulent and the less virulent group. It is important to note that the most virulent isolates originated from Minas Gerais, being one from Uberaba and five from Viçosa, while the less virulent group contained the isolates from São Paulo, Parana, Paraiba and Mato-Grosso, suggesting relationship between isolate's virulence and its geographic origin. The nonsignificant isolate $\mathrm{x}$ genotype interaction suggests that any of the isolates could be used for evaluation of resistance to ramulose. Cluster analysis is more commonly used for evaluating similarity among the pathogenic isolates than for similarity among the races (21). Thus in a quantitative pathosystem, where there are no physiological races sensu Robinson, similarity among isolates for their virulence on a range of genotypes can be determined using cluster analysis and the most appropriate isolate can be selected.

\section{REFERENCES}

01. Alves, J. M. A.; Sediyama, T.; Sampaio, N. F.; Berger, P. G.; Costa, H. Resistência de híbridos $\mathrm{F}_{1}$ e algodoeiro e seus progenitores a ramulose causada por Colletotrichum gossypii South var. cephalosporioides. Fitopatologia Brasileira, Fortaleza, v. 22, n. 3, p.242, 1997.

02. Andrade, D. F. A. A.; Lamas, F. M.; Fortuna, P. A. Comportamento de cultivares/linhagens de algodoeiro frente à ocorrência de doenças em chapadão do Sul, MS, safra 19988/1999. In: Congresso Brasileiro de Algodão, 1999, 2. Ribeirão Preto. Anais... Campina Grande: EMBRAPA-CNPA, 1999. p. 458-460.

03. Bailey, B. A.; Schuh, W.; Frederiksen, R. A.; Bockholt, A. J.; Smith, J. D. Indentification of "slow rusting"resistance to Puccinia polysora in maize inbreds and single crosses. Plant Disease, St. Paul, v. 71, n.6, p. 518-521, 1987.

04. Bailey, J. A.; Nash, C.; Morgan, L. W.; O`Connell, R. J.; Tebeest, D. O. Molecular taxonomy of Colletotrichum species causing anthracnose on the Malvaceae. Phytopathology, St. Paul, v. 86, n 10, p.1076-1083, 1996.

05. Carvalho, L. P.; Carvalho, J. M. F. C.; Lima, E. F.; Cavalcante, F. B. Influência da concentração de esporos na patogenicidade de Colletotrichum gossypii South. var. cephalosporioides A. S. Costa e avaliação da resistência de cultivares e linhagens de algodoeiro herbáceo a ramulose. Fitopatologia Brasileira, Fortaleza, v. 6, n. 3, p.395-402, 1981.

06. Carvalho, L. P.; Lima, E. F.; Ramalho, F. S.; Lukefahr, M. J.; Carvalho, J. M. F. C. Influência da pilosidade do algodoeiro na expressão de sintomas de ramulose. Fitopatologia Brasileira, Fortaleza, v. 10, n. 3, p.649-654, 1985.

07. Carvalho, L. P.; Cruz, C. D.; Morais, C. F.; Lima, E. F. Hereditariedade da resistência do algodoeiro à ramulose causada por $\mathrm{Co}$ lletotrichum gossypii South var. cephalosporioides A. S. Costa. Revista Ceres, Viçosa, v. 41, n. 2, p. 245-262, 1994.

08. Cia, E. Ocorrência e reconhecimento das doenças de algodoeiro anual Gossypium hirsutum L. no Brasil. Summa Phytopathologica, Botucatu, v 3, n.3, p.167-193, 1977.

09. Costa , A. S.; Fraga Júnior, C. G. Sobre a natureza da ramulose 
ou superbrotamento do algodoeiro. Jornal de Agronomia, Piracicaba, v. 2, n. 4, p. 151-160, 1939.

10. Costa, A. S. Investigações sobre ramulose. Relatório. Seção de Algodão no 1012. Campinas, Instituto Agronômico. Campinas. 1941. 42p.

11. Euclides, R. F. Sistema para análise estatística e genética. Viçosa: Universidade Federal de Viçosa,1983. 53 p.

12. Farias, F. J. C.; Freire, E. C.; Carvalho, L. P.; Arantes, E. M.; Sousa, M.; Oliveira, L. C.; Moresco, R. Avaliação de genótipos de algodoeiro herbáceo com relação à virose e à ramulose. In: Congresso Brasileiro de Algodão, 1. Fortaleza. Anais... Campina Grande: EMBRAPA-CNPA, 1997. p. 426-429.

13. Freire, E. C.; Farias, F. J. C.; Aguiar, P. H.; Araújo, A. E. Comportamento de novas cultivares e linhagens com relação a doenças no centro-Oeste - safra 1998/1999. In: Congresso Brasileiro de Algodão, 2. , 1999, Ribeirão Preto. Anais... Campina Grande: EMBRAPA-CNPA, 1999, p. 454-457.

14. Freire, E. C.; Santos, A. M.; Arantes, E. M.; Paro, H.; Farias, F. J. C. Diagnóstico da cultura do algodão em Mato Grosso 1996. Campina Grande: EMBRAPA-CNPA/EMPAER-MT, 1997. 31p. (Documentos, 49).

15. Fuzatto, M. G.; Cia, E.; Chiavegato, E. J.; Pizzinatto, M. A.; Erismar, E. J.; Zimback, L. Variabilidade genética e potencial de seleção para resistência à ramulose em cultivares e linhagens avançadas de algodoeiro. In: Congresso Brasileiro de Algodão, 2., Ribeirão Preto. Anais... Campina Grande: EMBRAPACNPA, 1999. p. 473-475.

16. Godinho, V. P. C.; Ramalho, A. R.; Freire, E. C.; Farias, F. J. C.; Utumi, M. M.; Prado, E. E.; Ferro, G. O. Avaliação de cultivares do algodoeiro herbáceo para região de Ouro Preto do Oeste, RO. In: Congresso Brasileiro de Algodão, 1, 1997, Fortaleza. Anais... Campina Grande: EMBRAPA-CNPA, 1997. p. 401-403.

17. Juliatti, F. C.; Ruano, O. Algodão. In: Vale, F. X. R.; Zambolim, L. (Ed.). Controle de doenças de plantas: grandes culturas. Viçosa - MG: Departamento de Fitopatologia, Universidade Federal de Viçosa; Brasília; Ministério da Agricultura e do Abastecimento, 1997. v. 2, p. 555-570.

18. Kimati, H. Doenças do algodoeiro. In: Galli, F.; Tokeshi, H.; Carvalho, P. C. T. de ; Balmer, E.; Kimati, H.; Cardoso, C. O. N.; Salgado, C. L. Manual de fitopatologia. 2 ed. São Paulo: Ceres, 1980. p. 143-158.

19. Lanza, M. A.; Fallieri, J.; Guimarães, F. B.; Reis, E. I.; Silva, P. J. Avaliação do progresso da ramulose do algodoeiro. In: Congresso Brasileiro de Algodão, 2., 1999, Ribeirão Preto. Anais... Campina Grande: EMBRAPA-CNPA, 1999. p. 485-487.

20. Leonard, K. J.; Fry, W. E. Plant diseases epidemiology. New York: Mac Millan Publishing Company, 1986. 372p.
21. Liberato, J. R. Aplicações de técnicas de análise multivariada em fitopatologia 1995. 144p. Dissertação (Mestrado em Fitopatologia) - Universidade Federal de Viçosa, Viçosa, 1995.

22 .Lima, E. R.; Carvalho, L. P.; Santos, E. O.; Carvalho, J. M. F. C. Avaliação de germoplasma de algodoeiro para resistência à ramulose causada por Colletotrichum gossypii var. cephalosporioides. Fitopatologia Brasileira, Fortaleza, v. 9, n. 3, p. 561565, 1984.

23. Lima, E. Carvalho, J. M. F. C.; Carvalho, L. P. Costa, J. N. Transporte e transmissibilidade de Colletotrichum gossypii var. cephalosporioides através de semente de algodoeiro. Fitopatologia Brasileira, Fortaleza, v. 10, n. 1, p.99-109, 1985.

24. Lima, E.F.; Chaves, G. M. Variabilidade de Colletotrichum gossypii var. cephalosporioides. Fitopatologia Brasileira, Fortaleza, v. 17, n. 1, p.61-66, 1992.

25. Lima, E. F.; Carvalho, J. M. F. C.; Batista, F. A. S.; Santos, J. W.; Carvalho, L. P. Seleção recorrente para resistência à ramulose do algodoeiro (Gossypium hirsutum L. var. latifolium Hutch). Pesquisa Agropecuária Brasileira, Brasilia, v. 31, n. 2, p. 101104, 1996.

26. Parlevliet, J. E. Components of resistance that reduce the rate epidemic development. Annual Review Phytopathology, Palo Alto, v. 17, p.203-222, 1979.

27. Santos, G. R.; Zambolim, L.; Ribeiro Do Vale, F. X.; Vieira, J. M. Progresso e gradiente da ramulose do algodoeiro. Fitopatologia Brasileira, Fortaleza, v. 19, n. 3, p. 390-393, 1994.

28. Stradioto, M. F. Variabilidade de Colletotrichum gloeosporioides (Penzig) Penzig \& Sacc. e resistência de seringueira (Hevea spp.) ao patógeno. 1993. 63p. Dissertação (Mestrado em Fitopatologia) - Universidade Federal de Viçosa, Viçosa - MG, 1993.

29. Tanaka, M. A. S.; Menten, J. O. M. Variação patogênica e fisiológica de Colletotrichum gossypii var. cephalosporioides em algodoeiro. Summa Phytopathologica, Botucatu, v. 18, n. 1, p.138-145, 1992.

30. Torres, J. C.; Ventura, J. A. AVACPD: um programa para calcular a área e volume abaixo da curva de progresso da doença. Fitopatologia Brasileira, Fortaleza, v. 16, n. 2, p. 52, 1991.

31. Von Pinho, R. G.; Von Pinho, E. V. R.; Fraga, A. C.; Machado, J. C. Avaliação de fontes de resistência à ramulose do algodoeiro causada por Colletotrichum gossypii var. cephalosporioides. Ciência e Agrotec. v. 21, n. 3, p. 253-259, 1997. 